\title{
Transcatheter aortic valve replacement for aortic regurgitation in Asians
}

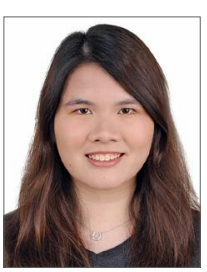

Erica L. Soong ${ }^{1}$, MBBS; Yi Jing Ong ${ }^{1}$, MBBS; Jamie S.Y. Ho², MB BChir;

Nicholas W.S. Chew ${ }^{3}$, MB ChB; William K.F. Kong ${ }^{3,4}$, MB ChB; Tiong-Cheng Yeo ${ }^{3,4}$, MBBS; Ping Chai ${ }^{3,4}$, MBBS; Edgar L.W. Tay ${ }^{3}$, MBBS; Kent A. Tan³, MBBS; Yinghao Lim³ ${ }^{3}$ MBBS; Ivandito Kuntjoro ${ }^{3}, \mathrm{MBBS}$; Ching-Hui $\mathrm{Sia}^{3,4 *}, \mathrm{MBBS}$

1. Yong Loo Lin School of Medicine, National University of Singapore, Singapore; 2. Academic Foundation Programme, North Middlesex University Hospital NHS Trust, London, United Kingdom; 3. Department of Cardiology, National University Heart Centre Singapore, Singapore; 4. Department of Medicine, Yong Loo Lin School of Medicine, National University of Singapore, Singapore

E.L. Soong and Y.J. Ong contributed equally to the manuscript.

This paper also includes supplementary data published online at: https://www.asiaintervention.org/doi/10.4244/AIJ-D-21-00007

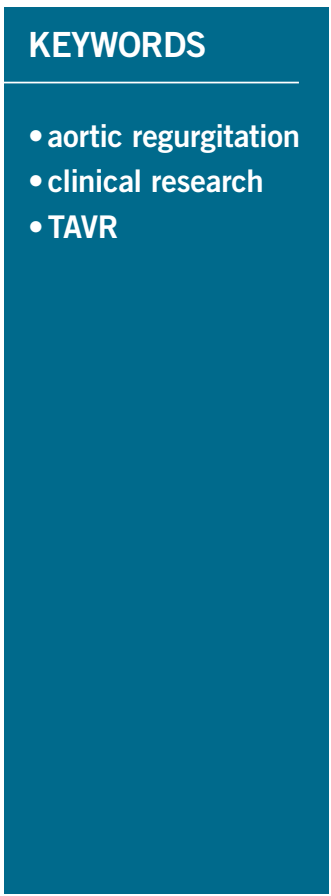

\section{Abstract}

Aims: Although surgical aortic valve replacement (SAVR) is currently the recommended intervention for patients with native AR without aortic stenosis, a significant proportion of Asian patients undergo transcatheter aortic valve replacement (TAVR), which has not been studied fully for safety and outcomes. This systematic review aims to examine the characteristics and outcomes of Asian patients with pure native aortic regurgitation (AR) undergoing TAVR.

Methods and results: PubMed, Embase, Scopus, Web of Science and Cochrane CENTRAL were systematically searched for randomised controlled trials, observational studies and case reports published from inception to 2 April 2020, involving patients of Asian ethnicity with pure native aortic regurgitation who had undergone TAVR. Our primary outcome was all-cause mortality, with secondary outcomes including all major complications. Five studies ( $n=274$ patients) and eight case reports were included. Device success was reported in $94.9 \%$ of the patients, the all-cause mortality rate was $4.4 \%, 2.5 \%$ were converted to SAVR, $1.7 \%$ had post-operative paravalvular leak and $6.7 \%$ required permanent pacemaker implantation.

Conclusions: TAVR has demonstrated acceptable safety and efficacy in Asian patients with pure AR displaying low mortality rates and few adverse outcomes.

*Corresponding author: National University Heart Centre Singapore, 1E Kent Ridge Road, NUHS Tower Block Level 9 , Singapore 119228.E-mail: ching_hui_sia@nuhs.edu.sg 


\section{Abbreviations}

AR aortic regurgitation

IQR interquartile range

NOS Newcastle-Ottawa Quality Assessment Scale

NYHA New York Heart Association

PPM permanent pacemaker

RCT randomised controlled trial

SAVR surgical aortic valve replacement

STS Society of Thoracic Surgeons

TAVR transcatheter aortic valve replacement

VARC-2 Valve Academic Research Consortium-2

\section{Introduction}

Surgical aortic valve replacement (SAVR) is currently the treatment of choice for patients with severe pure native aortic regurgitation (AR) requiring intervention ${ }^{1}$. However, there remains a therapeutic dilemma for patients with severe AR, in particular those with reduced left ventricular function, as studies have shown that postoperative outcomes are much worse for this group of patients ${ }^{2}$. These patients are mostly considered high-risk or inoperable and thus, there remains a gap in current management for patients with symptomatic severe $\mathrm{AR}$ who are at high risk for surgery.

Transcatheter aortic valve replacement (TAVR) was originally indicated as a treatment for patients with severe symptomatic aortic stenosis and has been shown to have comparable results to $\mathrm{SAVR}^{3}$. Since then, TAVR has been used more and more for off-label indications such as valve-in-valve and native AR interventions. Recently, the US Food and Drug Administration has approved the use of the Medtronic Evolut ${ }^{\mathrm{TM}}$ (Medtronic, Minneapolis, MN, USA) TAVR platform in bicuspid aortic valve disease, further expanding the use of TAVR in younger, lower-risk patients ${ }^{4}$. Pure severe native aortic regurgitation is defined as the presence of severe AR not associated with significant aortic stenosis (AS) or failed surgical valve. TAVR has emerged as a potential treatment option for this patient population and it may offer better outcomes than optimal medical treatment for inoperable severe AR patients 5 .

Although aortic regurgitation has a higher prevalence in the elderly Asian population as compared to Western patients ${ }^{6}$, it remains a relatively under-researched field. Moreover, anatomic differences in the Asian population (including eccentric valvular calcification and a smaller aortic valve annulus) may pose unique challenges to TAVR. Hence, this systematic review aims to study the characteristics and outcomes of TAVR performed in an Asian population with pure native aortic regurgitation in the hope of better aiding clinicians to consider it as a possible intervention for their patients.

\section{Methods \\ LITERATURE SEARCH}

Five databases were searched electronically in April 2020: PubMed, Embase, Scopus, Web of Science and Cochrane
CENTRAL. Study selection, data extraction, risk of bias assessment and quality assessment were conducted by two independent reviewers (E.L. Soong, Y.J. Ong). Data management and synthesis was done using Rayyan QCRI (Rayyan Systems Inc, Cambridge, MA USA). The following Boolean operators were used: ("aortic regurgitation" OR "aortic valve regurgitation" OR "aortic insufficiency" OR "aortic valve insufficiency" OR "AR" OR "AI") AND ("transcatheter aortic valve implantation" OR "transcatheter aortic valve replacement" OR "TAVI" OR "TAVR").

\section{STUDY SELECTION}

Studies were selected if they met the following inclusion criteria:

1. patients with native aortic regurgitation (no concomitant aortic stenosis)

2. studies from Asian centres, or studies in non-Asian centres specifically reporting outcomes of Asian patients

The exclusion criteria were as follows:

1. prior intervention to the aortic valve (prosthetic or repaired aortic valve)

2. concomitant procedure(s) at the time of TAVR

3. paediatric population (defined as patients aged $<18$ years old)

4. no report of mortality or morbidity

Randomised controlled trials (RCTs), observational studies (prospective, retrospective, case-controlled) and case reports were included. Articles without any primary data such as abstracts, systematic reviews, meta-analyses, comments, letters to the editor, and expert opinions were excluded.

To prevent duplicate reporting of patient cohorts, whenever a similar co-author was identified between abstracts, the publication with the greater number of patients was included unless the patient population was clearly distinct between studies after fulltext review.

\section{RISK OF BIAS AND QUALITY ASSESSMENT}

The risk of bias of the included studies was assessed independently by two authors (E.L. Soong, Y.J. Ong) and is presented in a risk of bias table (Supplementary Table 1-Supplementary Table 3). Risk of bias for the cohort study was assessed using the NewcastleOttawa Quality Assessment Scale (NOS) ${ }^{7}$ while risk of bias for the case series was assessed using the Institute of Health Economics Quality Appraisal Checklist ${ }^{8}$. Case reports were assessed using the scale developed by Murad et $\mathrm{al}^{9}$.

\section{DATA EXTRACTION}

Data on key baseline characteristics and outcomes were extracted independently by two reviewers (E.L. Soong, Y.J. Ong) and stored on pre-made proformas. Outcomes of interests included all-cause mortality, cardiovascular mortality, myocardial infarction, stroke or transient ischaemic attack, major or life-threatening bleeding, major vascular complication, acute kidney injury ( $\geq$ stage 2 ), permanent pacemaker implantation, infective endocarditis, paravalvular leak, device migration and valve thrombosis. 


\section{STATISTICAL ANALYSIS}

For prevalence and continuous outcomes, we performed metaanalyses of proportions using the Freeman-Tukey transformation, and mean differences respectively. The random-effects model was performed to pool the outcomes. Meta-analyses were performed using OpenMeta[Analyst]. Subgroup analysis was conducted by stratifying studies according to: (1) type of valves (J-Valve ${ }^{\mathrm{TM}}$ [Jiecheng Medical Technology Co, Suzhou, China] vs CoreValve ${ }^{\circledR}$ [Medtronic]) and (2) mean logistic EuroSCORE $(<20$ and $>20)$ for device success and all-cause mortality respectively. All continuous variables were presented as means \pm standard deviation for parametric variables and medians with interquartile range (IQR) for non-parametric variables. Categorical variables are described as number (\%). The $\mathrm{I}^{2}$ statistic was used to assess heterogeneity and a value of $\mathrm{I}^{2}=25 \%-50 \%$ was considered mild, $50 \%-75 \%$ as moderate and $>75 \%$ as severe. A p-value of $<0.05$ was considered statistically significant in all cases.

As this was a systematic review and meta-analysis based on published data, ethical review and specific informed consent were not required.

\section{Results}

\section{LITERATURE SEARCH AND STUDY CHARACTERISTICS}

The initial search revealed a total of 9,727 potential articles. After exclusion, 13 reports remained for analysis (three full texts, two conference abstracts and eight case reports). The PRISMA flow chart (Figure 1, Supplementary Table 4) gives an overview of the literature search. The studies (excluding case reports) included a total of 274 patients undergoing TAVR for native AR and were generally of moderate quality, with risk of selection bias and reporting bias (Supplementary Table 1-Supplementary Table 3).

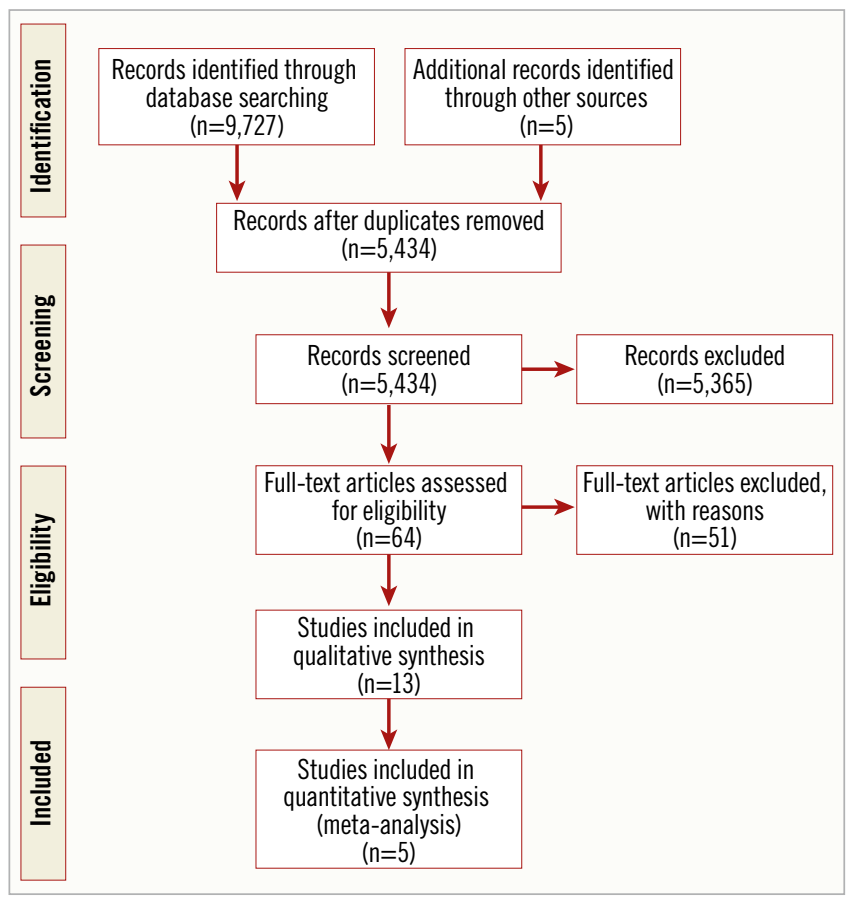

Figure 1. PRISMA flow diagram.

One study had a multicentre design while the remaining four were single-centre. The mean age of the patients ranged from 72.6 to 75.2 years, and the mean logistic EuroSCORE ranged from 10.89 to 23.35. Relevant individual study and baseline patient characteristics are displayed in Table 1. The pooled baseline characteristics are shown in Table 2. Case reports were analysed separately.

Only two studies ${ }^{10,11}$ reported the quantitative assessment of AR severity - of which most of the patients (76.8\%) had severe

Table 1. Study characteristics \& baseline patient characteristics.

\begin{tabular}{|c|c|c|c|c|c|c|c|c|}
\hline First author, year & Design & $\begin{array}{c}\text { Patients, } \\
\text { n }\end{array}$ & Age, years & Male (\%) & $\begin{array}{c}\text { NYHA Class III/IV, } \\
\text { n (\%) }\end{array}$ & LVEF, \% & $\begin{array}{c}\text { Logistic } \\
\text { EuroSCORE, \% }\end{array}$ & STS Score, \% \\
\hline Deng, 2018 & Cohort & 30 & $72.8 \pm 4.3$ & $21(70)$ & $29(96.7)$ & $57.0 \pm 10.3$ & $20.9 \pm 4.8$ & NR \\
\hline Liu L L, 2019 & Case series & $\begin{array}{l}\text { Grp 1: } 52 \\
\text { Grp 2: } 82\end{array}$ & $\begin{array}{l}\text { Grp 1: } 73.2 \pm 4.4 \\
\text { Grp 2: } 73.1 \pm 7.3\end{array}$ & $\begin{array}{l}\text { Group 1: } 39 \text { (75.0) } \\
\text { Group 2: } 61(74.4)\end{array}$ & $\begin{array}{l}\text { Grp 1: } 51 \text { (98.1) } \\
\text { Grp 2: } 80 \text { (97.6) }\end{array}$ & $\begin{array}{l}\text { Grp 1: } 55.52 \pm 11.24 \\
\text { Grp 2: } 50.12 \pm 13.09\end{array}$ & $\begin{array}{l}\text { Grp 1: } 10.62 \pm 5.28 \\
\text { Grp 2: } 12.16 \pm 7.52\end{array}$ & $\begin{array}{l}\text { Grp 1: } 9.17 \pm 4.5 \\
\text { Grp 2: } 10.23 \pm 5.81\end{array}$ \\
\hline Liu H, 2018 & Case series & 43 & $73.9 \pm 5.7$ & $30(69.8)$ & $14(32.6)$ & $55.9 \pm 10.8$ & $25.5 \pm 5.3$ & NR \\
\hline Liu W, 2019 & Abstract & 53 & $76.4 \pm 5.2$ & NR & NR & NR & NR & $6.3 \pm 1.8$ \\
\hline Yin, 2018 & Abstract & 14 & $74.3 \pm 16.5$ & NR & NR & $55.2 \pm 11.0$ & $16.4 \pm 8.5$ & NR \\
\hline Chiam, 2014 & Case report & 1 & 43 & $1(100)$ & $1(100)$ & 45 & NR & NR \\
\hline Kurazumi, 2014 & Case report & 1 & 77 & $0(0)$ & $1(100)$ & NR & NR & NR \\
\hline Zhu, 2015 & Case report & 1 & 74 & $1(100)$ & NR & 48 & 21 & NR \\
\hline Liu W, 2019 & Case report & 1 & 78 & $1(100)$ & NR & 47 & NR & 8.84 \\
\hline Gopalamurugan, 2016 & Case report & 1 & 45 & $1(100)$ & NR & NR & NR & NR \\
\hline Liu X, 2016 & Case report & 1 & NR & NR & NR & NR & NR & NR \\
\hline Tan, 2017 & Case report & 1 & 38 & $0(0)$ & NR & 45 & NR & NR \\
\hline Cheung, 2017 & Case report & 1 & 75 & $1(100)$ & NR & $20-25$ & NR & 9.9 \\
\hline \multicolumn{9}{|c|}{$\begin{array}{l}\text { Pooled baseline characteristics are summarised in Table 2. The median age of the population studied was } 73.9 \text { years old (IQR } 72.6 \text {-75.2). Three studies reported on the gender proportion of } \\
\text { their subjects, with } 72.9 \% \text { of the reported population being male. From the three studies that reported data, a majority (84.1\%) of the population had severe symptoms (NYHA Class III/IV). Two } \\
\text { studies reported on the STS score (mean 8.52\%) and four studies reported the log-EuroSCORE (mean 17.12\%). EuroSCORE: European System for Cardiac Operative Risk Evaluation; Grp: group; } \\
\text { NR: not reported; NYHA: New York Heart Association; STS: Society of Thoracic Surgeons }\end{array}$} \\
\hline
\end{tabular}


AR while $20.9 \%$ of the patients had moderate AR. Only one full report ${ }^{12}$ recorded the AR aetiology of its included patients, with the majority of cases due to degeneration $(72.1 \%)$ with rheumatic heart disease (23.2\%) and bicuspid aortic valve (4.7\%) accounting for the remainder of the cases. Two case reports ${ }^{13,14}$ also recorded AR aetiology, both secondary to infective endocarditis. None of the studies or case reports reported other aortic valve characteristics such as valve calcification or shape.

\section{PROCEDURAL INFORMATION}

The reason for choosing TAVR over SAVR was mentioned in four studies and three case reports, with all quoting high or prohibitive surgical risk or severe AR as the main reason SAVR was declined. Four full studies used J-Valve with a transapical approach while one full study used CoreValve with a transfemoral approach. The mean valve size chosen for the procedure based on the available data from three full studies was $26.3 \mathrm{~mm}$ (IQR 26.0-26.6). The device used and valve size varied in the case reports based on the specific patient's requirements. Breakdown of procedural information for each study can be found in Table 3.

Of note, two full studies and five case reports reported the use of general anaesthesia for TAVR, while the other three full studies and three case reports did not specify the type of anaesthesia used. Additionally, two studies and five case reports used transoesophageal echocardiogram (TEE) guidance in the procedure. No information on oversizing of the valve or rapid pacing during the procedure was available.

\section{OUTCOMES AND META-ANALYSIS}

Details on the clinical outcomes for each study can be found in Table 4. Results of the meta-analysis are summarised in Figure 2 and the Central illustration. Detailed forest plots outlining the effect size of each study are given in Supplementary Figure 1, Supplementary Figure 2.
Table 2. Pooled baseline patient characteristics.

\begin{tabular}{|c|c|c|}
\hline \multicolumn{2}{|c|}{ Demographics } & $\begin{array}{c}\text { No. (\% of available data) } \\
n=274\end{array}$ \\
\hline \multicolumn{2}{|c|}{ Age, years, median (IQR) } & $73.9(72.6-75.2)$ \\
\hline \multicolumn{2}{|c|}{ Male } & $151(72.9)$ \\
\hline \multicolumn{3}{|l|}{ Comorbidities } \\
\hline \multicolumn{2}{|c|}{ Diabetes mellitus } & $30(14.5)$ \\
\hline \multicolumn{2}{|c|}{ Hypertension } & $136(65.7)$ \\
\hline \multicolumn{2}{|c|}{ Atrial fibrillation } & $38(18.4)$ \\
\hline \multicolumn{2}{|c|}{ Chronic obstructive pulmonary disease } & $118(57.0)$ \\
\hline \multicolumn{2}{|c|}{ Chronic kidney disease } & $30(17.6)$ \\
\hline \multicolumn{2}{|c|}{ Coronary artery disease } & $57(27.5)$ \\
\hline \multicolumn{2}{|c|}{ Cerebrovascular accident } & $85(41.1)$ \\
\hline \multicolumn{3}{|c|}{ Functional status } \\
\hline \multicolumn{2}{|c|}{ NYHA Class III/IV } & $174(84.1)$ \\
\hline \multicolumn{2}{|c|}{ LVEF, median (IQR) } & $54.6(51.9-57.3)$ \\
\hline \multicolumn{3}{|c|}{ Indication for TAVI } \\
\hline \multicolumn{2}{|c|}{ STS score, mean (IQR) } & $8.52(5.86-11.18)$ \\
\hline \multicolumn{2}{|c|}{ Logistic EuroSCORE, mean (IQR) } & $17.12(10.89,23.35)$ \\
\hline \multicolumn{3}{|c|}{ Aortic valve characteristics } \\
\hline \multirow{2}{*}{$\begin{array}{l}\text { Reported AR } \\
\text { severity }\end{array}$} & Moderate to severe & $37(20.9)$ \\
\hline & Severe & $136(76.8)$ \\
\hline \multicolumn{3}{|c|}{$\begin{array}{l}\text { AR: aortic regurgitation; EuroSCORE: European System for Cardiac } \\
\text { Operative Risk Evaluation; IQR: interquartile range; LVEF: left ventricular } \\
\text { ejection fraction; NYHA: New York Heart Association; STS: Society of } \\
\text { Thoracic Surgeons }\end{array}$} \\
\hline
\end{tabular}

\section{DEVICE SUCCESS}

All five studies reported device success, which ranged from $96.2 \%$ to $100 \%$ with a summary estimate of $94.9 \%$ (88.7\%-99.0\%; $\left[\mathrm{I}^{2}=66.45\right]$ ), and moderate statistical heterogeneity (Supplementary Figure 1). On subgroup analysis by valve device used, 252 (96.9\%)

Table 3. Procedural information.

\begin{tabular}{|c|c|c|c|c|c|c|}
\hline First author, year & Reason SAVR declined & Device & Access & Valve size, mm & Anaesthesia & TEE guidance \\
\hline Deng, 2018 & $N R$ & J-valve & Transapical & $25.8 \pm 1.3$ & $\mathrm{GA}$ & NR \\
\hline Liu L L, 2019 & High-risk & J-valve & Transapical & $\begin{array}{l}\text { Grp 1: } 26.2 \pm 1.6 \\
\text { Grp 2: } 26.6 \pm 2.2\end{array}$ & NR & Yes \\
\hline Liu H, 2018 & High-risk or prohibitive & J-valve & Transapical & $26.4 \pm 0.9$ & $\mathrm{GA}$ & Yes \\
\hline Liu W, 2019 & Severe AR & J-valve & Transapical & NR & NR & NR \\
\hline Yin, 2018 & High-risk & CoreValve & Transfemoral & NR & NR & NR \\
\hline Chiam, 2014 & Prohibitive & CoreValve & Transfemoral & 29 & $\mathrm{GA}$ & Yes \\
\hline Kurazumi, 2014 & NR & NR & NR & NR & NR & NR \\
\hline Zhu, 2015 & High-risk & J-valve & Transapical & 23 & $\mathrm{GA}$ & Yes \\
\hline Liu W, 2019 & NR & Venus A-Valve & NR & 29 & $\mathrm{GA}$ & No \\
\hline Gopalamurugan, 2016 & NR & CoreValve Evolut $\mathrm{R}$ & NR & NR & NR & Yes \\
\hline Liu X, 2016 & NR & NR & NR & NR & $\mathrm{GA}$ & Yes \\
\hline Tan, 2017 & NR & NR & NR & NR & NR & NR \\
\hline Cheung, 2017 & Prohibitive & CoreValve Evolut R & Transfemoral & 34 & $\mathrm{GA}$ & Yes \\
\hline
\end{tabular}


Table 4. Clinical outcomes.

\begin{tabular}{|c|c|c|c|c|c|c|}
\hline First author, year & $\begin{array}{c}\text { Device success, } \\
\text { n }(\%)\end{array}$ & $\begin{array}{l}\text { Conversion to } \\
\text { SAVR, n (\%) }\end{array}$ & Follow-up & $\begin{array}{c}\text { All-cause } \\
\text { mortality, n (\%) }\end{array}$ & PPI, n (\%) & PVL, n (\%) \\
\hline Deng, 2018 & $30(100)$ & $0(0)$ & 12 months & $0(0)$ & NR & $2(6.7)$ \\
\hline Liu L L, 2019 & $\begin{array}{l}\text { Grp 1: } 50(96.2) \\
\text { Grp 2: } 79(96.3)\end{array}$ & $\begin{array}{l}\text { Grp 1: } 1 \text { (1.9) } \\
\text { Grp 2: } 3 \text { (3.7) }\end{array}$ & 30 days & $\begin{array}{l}\text { Grp 1: } 0(0) \\
\text { Grp 2: } 3(3.7)\end{array}$ & $\begin{array}{l}\text { Grp 1: } 5(9.6) \\
\text { Grp 2: } 7(8.5)\end{array}$ & $\begin{array}{l}\text { Grp 1: } 1(1.9) \\
\text { Grp 2: } 0(0)\end{array}$ \\
\hline Liu H, 2018 & $42(97.7 \%)$ & $1(2.3)$ & 12 months & $2(4.7)$ & $2(4.7)$ & $1(2.4)$ \\
\hline Liu W, 2019 & $51(96.2)$ & $2(5.7)$ & 30 days & $5(9.2)$ & $2(5.7)$ & $1(1.8)$ \\
\hline Yin, 2018 & $8(57.1)$ & $0(0)$ & 9 months & $2(14.3)$ & NR & NR \\
\hline Chiam, 2014 & $1(100)$ & $0(0)$ & 6 months & $0(0)$ & $0(0)$ & $0(0)$ \\
\hline Kurazumi, 2014 & $1(100)$ & $0(0)$ & 2 months & $0(0)$ & NR & NR \\
\hline Zhu, 2015 & $1(100)$ & $0(0)$ & 3 months & $0(0)$ & $0(0)$ & $0(0)$ \\
\hline Liu W, 2019 & $1(100)$ & $0(0)$ & NR & NR & $1(100)$ & $1(100)$ \\
\hline Gopalamurugan, 2016 & $1(100)$ & $0(0)$ & 2 months & $0(0)$ & $0(0)$ & $0(0)$ \\
\hline Liu X, 2016 & $1(100)$ & $0(0)$ & Until discharge & $0(0)$ & $0(0)$ & $0(0)$ \\
\hline Tan, 2017 & $1(100)$ & $0(0)$ & 3 months & $0(0)$ & NR & NR \\
\hline Cheung, 2017 & $1(100)$ & $0(0)$ & 1 week & $0(0)$ & $0(0)$ & $0(0)$ \\
\hline
\end{tabular}

out of 260 patients receiving a J-Valve had device success, compared to $8(57.1 \%)$ out of 14 patients receiving a CoreValve.

Of the eight patients who underwent TAVR with J-Valve and experienced device failure, six were converted to SAVR, one was successfully implanted with another J-valve and the reason for device failure was not stated for one patient. Of the six patients who underwent TAVR with CoreValve and experienced device failure, five had severe paravalvular leakage (PVL) and required a second valve implantation while one had moderate PVL.

\section{CONVERSION TO OPEN SURGERY}

Four studies reported the rate of conversion to open surgery, varying from $2.0 \%$ to $3.7 \%$, with a pooled estimate of $2.7 \%$ $\left(0.8 \%-4.7 \% ;\left[\mathrm{I}^{2}=0 \%\right]\right)$. Among the eight patients who were converted to open surgery, seven conversions were done intraoperatively. Six of these were due to valve migration, while one was due to severe PVL. The remaining patient had moderate PVL postoperatively and developed congestive heart failure oneweek post-op, thus requiring conversion to SAVR. Among the six patients with valve migration, no data on oversizing for their procedure was reported.

\section{ALL-CAUSE MORTALITY}

Four studies reported all-cause mortality and the 30-day mortality ranged from $2.2 \%$ to $9.4 \%$, with a pooled estimate of $2.8 \%(0.2 \%$ $\left.5.4 \% ;\left[\mathrm{I}^{2}=35.21 \%\right]\right)$ and mild between-study heterogeneity across three studies (Supplementary Figure 2). The nine-month mortality was reported as $14.3 \%$ ( 2 out of 14 patients) in one case series ${ }^{15}$, and the one-year mortality was $4.7 \%$ in another case series of 43 patients $^{11}$. Of the 12 patients who died, one patient had been converted to SAVR due to device migration and had a stroke onemonth post-op, three were due to cardiac causes, one due to digestive tract haemorrhage, three due to infection and four were not stated.

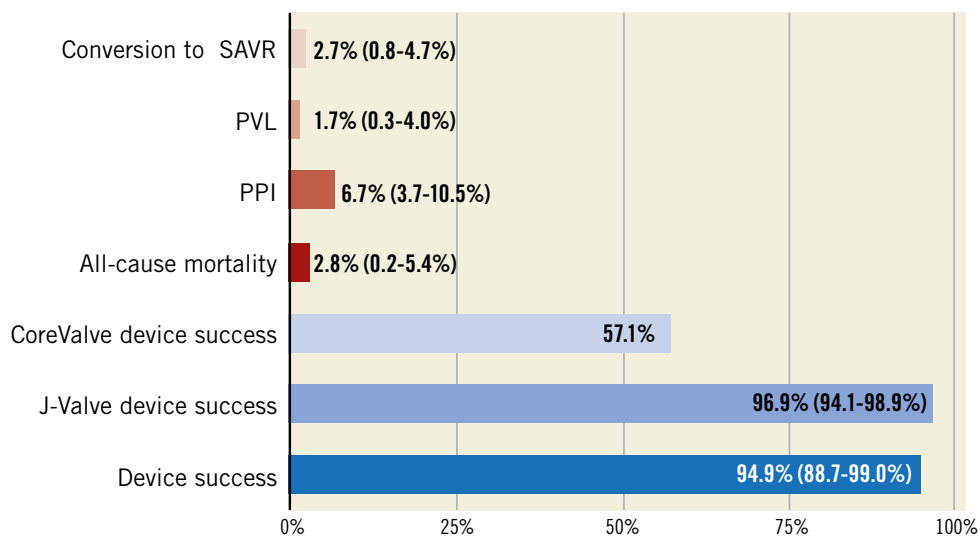

Figure 2. Bar graph showing pooled incidence of each clinical outcome, along with 95\% confidence interval. PPI: permanent pacemaker implantation; PVL: paravalvular leakage; SAVR: surgical aortic valve replacement 

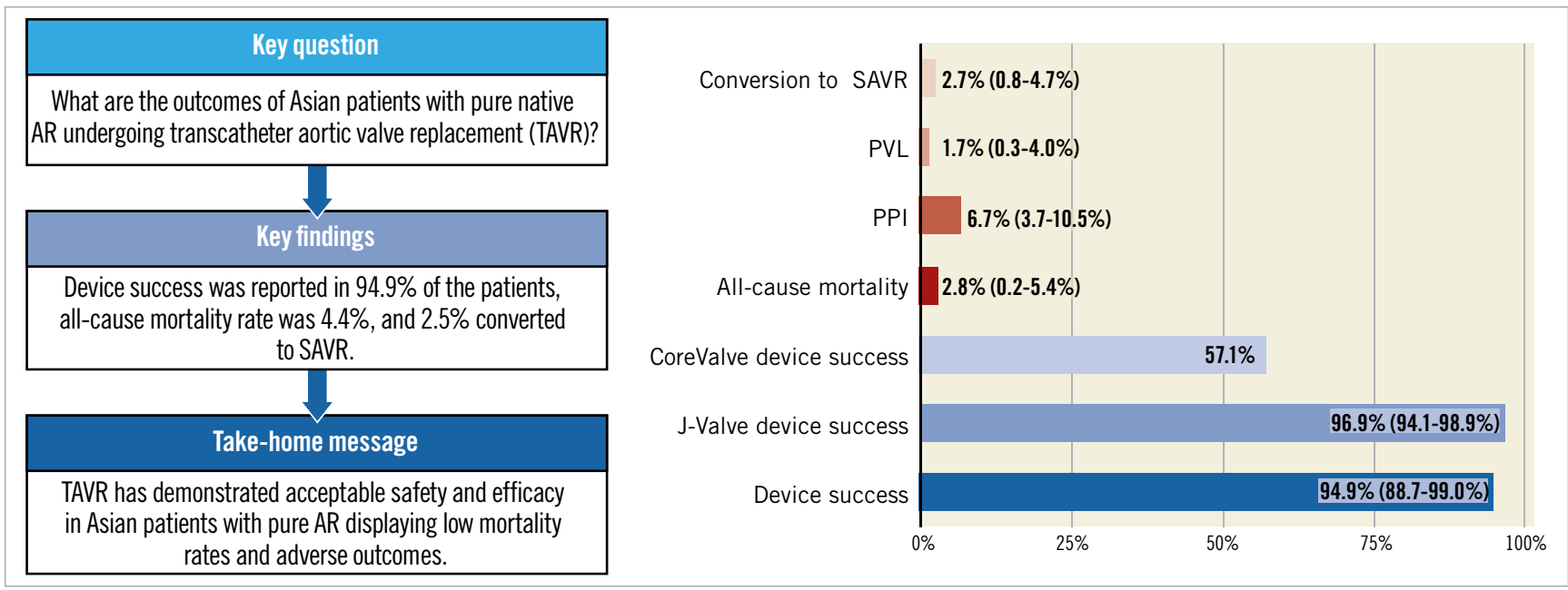

Central illustration. TAVR for pure native AR in the Asian population showed acceptable safety and efficacy outcomes. AR: aortic regurgitation; PPI: permanent pacemaker implantation; PVL: paravalvular leakage; SAVR: surgical aortic valve replacement

Subgroup analysis revealed that there was no significant difference in the mortality rate between subgroups of patients with logistic EuroSCORE $<20 \%(n=73)(3.1 \%)$ and those with logistic EuroSCORE $>20 \%(n=148)(3.2 \%)$.

\section{PARAVALVULAR LEAKAGE}

Four studies reported the rate of paravalvular leakage (moderate to severe), varying from $1.8 \%$ to $2.4 \%$, with a pooled estimate of $1.7 \%\left(0.3 \%-4.0 \% ;\left[I^{2}=0 \%\right]\right)$.

\section{PERMANENT PACEMAKER (PPM) IMPLANTATION}

Three studies reported the rate of post-procedural PPM implantation, varying from $4.7 \%$ to $5.6 \%$, with a pooled estimate of $6.7 \%$ $\left(3.7 \%-10.5 \%\right.$; $\left.\left[\mathrm{I}^{2}=0 \%\right]\right)$.

\section{Discussion \\ JUSTIFICATION OF TAVR IN NATIVE AR}

Current guidelines suggest that native AR patients who are symptomatic or with left ventricular ejection fraction (LVEF) $<50 \%$ should undergo surgical aortic valve replacement (SAVR), while similar patients who have contraindications for SAVR are to be treated conservatively with medical therapy ${ }^{1}$. However, there has been little research done on the efficacy of medical therapy in the treatment of AR, and that which has been done has come to conflicting conclusions on its effectiveness ${ }^{16}$. Moreover, patients with severe AR (NYHA Class III or IV) on medical treatment have a mortality rate of nearly $25 \%$ a year ${ }^{17}$. This shows that there exists an unmet clinical need for patients with inoperable severe AR.

Given that multiple studies have shown that TAVR has better outcomes than medical treatment for patients with inoperable aortic stenosis ${ }^{18}$, there is growing interest in a similar trajectory for AR patients with high or prohibitive surgical risk. From the studies that we have analysed, the all-cause mortality rate is comparable to that of the PARTNER trial assessing TAVR for aortic stenosis ${ }^{19}$ as well as various studies on SAVR in AR patients ${ }^{2}$. This indicates that despite unique challenges in its implementation that will be further elaborated on below, TAVR can still be considered as an alternative option for well-selected patients with acceptable efficacy and safety data.

\section{CHALLENGES OF TAVR IN NATIVE AR}

Native AR patients remain a challenge for TAVR procedure. While most severe AS is due to calcification and manifests later in life, the diverse aetiologies of AR result in more complex and diverse anatomy. In our included studies that reported on AR aetiology, a majority were due to degeneration but rheumatic heart disease, bicuspid aortic valve and infective endocarditis were also noted causes. In severe pure $A R$, the absence of annulus calcification makes device anchoring and stabilisation during deployment more challenging, increasing the risk of post-TAVR paravalvular leak and device embolisation ${ }^{20}$. AR is also frequently associated with dilatation of the aortic root which is usually accompanied by an extremely large annulus which exceeds most commercial TAVR valve devices ${ }^{21}$. This issue is often resolved by oversizing the valve for better anchoring to the annulus to make up for minimal calcification, thus preventing valve embolisation. Unfortunately, oversizing the valve may increase the risk of annular rupture and atrioventricular block. These anatomic challenges are reflected in the outcomes of our studies, in which paravalvular leak, permanent pacemaker implantation and conversion to SAVR due to valve migration are the most commonly reported complications. Due to limited data on annulus calcification, dilatation and shape, it is difficult for us to correlate whether these anatomical findings are strongly related to the procedural outcomes. Nonetheless, the rate of these complications is acceptable, and potentially with increased experience and future developments of new-generation valves specifically for native $\mathrm{AR}$, the rate of these complications can be decreased. 


\section{TYPES OF VALVES FOR TAVR IN NATIVE AR: J-VALVE VS COREVALVE}

Valve devices have evolved significantly since the first TAVR procedure was performed in 2002 and can generally be split into first- and second-generation devices. In the Asian studies, the most popular valve devices used to treat native AR were CoreValve (a first-generation Medtronic self-expandable valve) and J-Valve. This is different from other regions such as Europe where the JenaValve ([JenaValve Technology, Munich, Germany], a valve made specifically to treat native AR) has seen much higher use than the J-Valve. Subgroup analysis of our included studies revealed that the use of the newer-generation valves such as J-Valve have a much higher success rate compared to CoreValve, a trend that is comparable to other international studies on TAVR in AR using different generation valves ${ }^{21}$, with first-generation valves having device success ranging from $54 \%$ to $79 \%$ and second-generation valves having device success ranging from $81.1 \%$ to $100 \%$. With the available evidence in mind, it may be advisable for clinicians to consider second-generation valves such as the Medtronic Evolut $\mathrm{R}$ or other valves made specifically for native AR, such as the J-Valve, for this patient population. The much higher device success rate may have to do with the J-Valve's clip-based design over the native aortic valve leaflet alleviating the dependency on aortic annular calcification, while the Medtronic Evolut R has the benefit of being recapturable and repositionable.

\section{INTER-ETHNIC DIFFERENCES IN TAVR}

Racial differences in the vessel anatomy, representation in clinical trials and overall utilisation have been observed in previous studies $^{22}$. In Asian populations, the uptake of TAVR has been slow, with fewer than $10 \%$ of TAVRs worldwide performed in Asia despite its larger population ${ }^{23}$. There are few publications on the outcomes of TAVR in Asian populations, and no randomised controlled trials to date. Due to anatomical differences, TAVR has caused particular concern in the Asian population. Compared to Caucasians, Asians have a smaller aortic annulus area, a smaller left coronary cusp diameter, and a lower height of the left coronary ostia $^{24}$. One Korean study found that one-third of Asian patients have both a lower height of left coronary ostia and smaller sinuses of Valsalva, which increases the risk of coronary obstruction after $\mathrm{TAVR}^{25}$. Although a smaller aortic annulus theoretically reduces the risk of perivalvular leaks, it is unknown if the benefit is evident in Asian patients with AR. Observational studies and large registries showed that clinical outcomes of TAVR for aortic stenosis in Asian patients are generally good, with a procedural success rate of $97.5 \%$ and 30 -day mortality rate of $2.5 \%$ in an international Asian registry ${ }^{26}$. A prospective, multicentre, non-randomised trial in Japan found that clinical outcomes after TAVR in severe aortic stenosis were similar to a single-centre European cohort ${ }^{27}$. This study showed however, that the use of TAVR for AR in the Asian population is limited, particularly for Asians outside of China, and the gap in evidence may impede the adoption of TAVR in this large population.

\section{Limitations}

This systematic review has a number of limitations. First, given the novel off-label nature of TAVR as an intervention for AR patients especially in the Asian population, the pool of studies that we can analyse is currently very limited. Most of the studies identified were Chinese, therefore many of the other Asian countries and ethnicities were under-represented. Furthermore, only one study was a cohort study with a control group, the others being case series and case reports. None of the studies included had research data or clinical endpoints adjudicated through independent core labs, which exposed the results to observer and confirmation bias that may lead to overestimation of benefits and underestimation of complications. Selection bias was a factor as we were only able to find conference abstracts for six of our included studies. Second, reporting bias was also a factor, as some studies did not fully report on all the clinical outcomes we sought to collect data for, and some did not adhere to the current Valve Academic Research Consortium (VARC) criteria. More pressingly, many studies failed to provide information on certain baseline patient characteristics and procedural information which may have had an impact on the clinical outcomes of the studies. It should be noted that few of the studies recorded the AR aetiology of their included patients, and none recorded on aortic valve calcification. This is of interest to us as the absence of calcification in AR makes it more challenging to implant currently available valve devices by TAVR. There was also limited data on the procedural characteristics such as the use of rapid pacing, oversizing of valve, TEE guidance during TAVR, and other valve characteristics such as aortic valve shape, and annular dilatation all of which could influence the success rate. More information is required to correlate these factors with post-procedural outcomes and success. Third, our subgroup analysis was based on indirect comparisons between separate studies rather than on consecutive patients in a single centre using the same inclusion criteria. Finally, there are many devices, techniques and modes of access available for TAVR and the outcomes may differ based on operator experience, which may contribute to heterogeneity between studies, although statistical heterogeneity was small for most outcomes in this meta-analysis. Most of the studies included in this review were performed early in the adoption of TAVR, particularly for AR. Based on previous long-term studies that explored the trends in complications and outcomes of TAVR over time ${ }^{28}$, it would be expected that with better case selection, improved procedural techniques and increased experience, outcomes of TAVR for AR would improve. Hence, the outcomes from our systematic review may be less readily applicable to the broader contemporary population.

\section{Conclusions}

In this study, TAVR has demonstrated acceptable safety and efficacy in Asian patients with native AR, displaying low mortality rates and adverse outcomes. This is especially pertinent in AR patients with high or prohibitive surgical risk who are not candidates for SAVR, which is the current recommended intervention. Among Asian treatment, J-Valve is the preferred second-generation 
device and CoreValve the preferred first-generation device; other devices were used on a case-by-case basis. More studies, ideally randomised controlled trials, need to be performed in order to come to more solid conclusions.

\section{Impact on daily practice}

TAVR has demonstrated acceptable safety and efficacy in Asian patients with native AR, displaying low mortality rates and adverse outcomes. TAVR may be a suitable alternative in native AR, particularly in patients with high or prohibitive surgical risk for SAVR. However, additional studies are needed to confirm these findings.

\section{Funding}

C-H Sia was supported by the National University of Singapore Yong Loo Lin School of Medicine's Junior Academic Faculty Scheme.

\section{Conflict of interest statement}

The authors have no conflicts of interest to declare.

\section{References}

1. Nishimura RA, Otto CM, Bonow RO, Carabello BA, Erwin JP 3rd, Guyton RA, O'Gara PT, Ruiz CE, Skubas NJ, Sorajja P, Sundt TM 3rd, Thomas JD; ACC/AHA Task Force Members. 2014 AHA/ ACC Guideline for the Management of Patients With Valvular Heart Disease: executive summary: a report of the American College of Cardiology/American Heart Association Task Force on Practice Guidelines. Circulation. 2014;129:2440-92.

2. Dong N, Jiang W, Yin P, Hu X, Wang Y. Predictors of Long-Term Outcome of Isolated Surgical Aortic Valve Replacement in Aortic Regurgitation With Reduced Left Ventricular Ejection Fraction and Extreme Left Ventricular Dilatation. Am J Cardiol. 2020;125: 1385-90.

3. Reardon MJ, Van Mieghem NM, Popma JJ, Kleiman NS, Søndergaard L, Mumtaz M, Adams DH, Deeb GM, Maini B, Gada H, Chetcuti S, Gleason T, Heiser J, Lange R, Merhi W, Oh JK, Olsen PS, Piazza N, Williams M, Windecker S, Yakubov SJ, Grube E, Makkar R, Lee JS, Conte J, Vang E, Nguyen H, Chang Y, Mugglin AS, Serruys PW, Kappetein AP; SURTAVI Investigators. Surgical or Transcatheter Aortic-Valve Replacement in Intermediate-Risk Patients. N Engl J Med. 2017;376:1321-31.

4. Vincent F, Ternacle J, Denimal T, Shen M, Redfors B, Delhaye C, Simonato M, Debry N, Verdier B, Shahim B, Pamart T, Spillemaeker H, Schurtz G, Pontana F, Thourani VH, Pibarot P, Van Belle E. Transcatheter Aortic Valve Replacement in Bicuspid Aortic Valve Stenosis. Circulation. 2021;143:1043-61.

5. Arias EA, Bhan A, Lim ZY, Mullen M. TAVI for Pure Native Aortic Regurgitation: Are We There Yet? Interv Cardiol. 2019;14:26-30.

6. Pan W, Zhou D, Cheng L, Ge J. Aortic regurgitation is more prevalent than aortic stenosis in Chinese elderly population: Implications for transcatheter aortic valve replacement. Int $J$ Cardiol. 2015;201:547-8.
7. GA Wells BS, D O'Connell, J Peterson, V Welch, M Losos, P Tugwell. The Newcastle-Ottawa Scale (NOS) for assessing the quality of nonrandomised studies in meta-analyses The Ottawa Hospital Research Institute2019 [Available from: http://www.ohri. ca/programs/clinical_epidemiology/nos_manual.pdf]

8. Publications IoHE. IHE Quality Appraisal Checklist for Case Series Studies 2016 [Available from: https://www.ihe.ca/publications/ihe-quality-appraisal-checklist-for-case-series-studies]

9. Murad MH, Sultan S, Haffar S, Bazerbachi F. Methodological quality and synthesis of case series and case reports. BMJ Evid Based Med. 2018;23:60-3.

10. Liu L, Zhang J, Peng Y, Shi J, Qin C, Qian H, Xiao Z, Guo Y. Learning curve for transcatheter aortic valve replacement for native aortic regurgitation: Safety and technical performance study. Clin Cardiol. 2020;43:475-82.

11. Liu H, Yang Y, Wang W, Zhu D, Wei L, Guo K, Zhao W, Yang X, Zhu L, Guo Y, Wang W, Wang C. Transapical transcatheter aortic valve replacement for aortic regurgitation with a second-generation heart valve. J Thorac Cardiovasc Surg. 2018;156:106-16.

12. Deng MD, Wei X, Zhang XL, Li XD, Liu GY, Zhu D, Guo YQ, Tang H. Changes in left ventricular function in patients with aortic regurgitation 12 months after transapical transcatheter aortic valve implantation. Int J Cardiovasc Imaging. 2019;35:99-105.

13. Chiam PT, Ewe SH, Chua YL, Lim YT. First transcatheter aortic valve implantation for severe pure aortic regurgitation in Asia. Singapore Med J. 2014;55:103-5.

14. Gopalamurugan AB, Murali K, Jyotsana B, Jacob A, Bashi VV. TAVI for aortic regurgitation - India's first case with Corevalve Evolut R. Indian Heart J. 2016;68 Suppl 2:S4-7.

15. W-H Y. TCTAP A-116 Transcatheter Aortic Valve Implantation of a Self-expandable Valve for Pure Aortic Regurgitation Without Aortic Valve Calcification. Journal of the American College of Cardiology. 2018;71(16):S63-4.

16. Scognamiglio R, Fasoli G, Ponchia A, Dalla-Volta S. Longterm nifedipine unloading therapy in asymptomatic patients with chronic severe aortic regurgitation. J Am Coll Cardiol. 1990;16: 424-9.

17. Dujardin KS, Enriquez-Sarano M, Schaff HV, Bailey KR, Seward JB, Tajik AJ. Mortality and morbidity of aortic regurgitation in clinical practice. A long-term follow-up study. Circulation. 1999;99:1851-7.

18. Kapadia SR, Tuzcu EM, Makkar RR, Svensson LG, Agarwal S, Kodali S, Fontana GP, Webb JG, Mack M, Thourani VH, Babaliaros VC, Herrmann HC, Szeto W, Pichard AD, Williams MR, Anderson WN, Akin JJ, Miller DC, Smith CR, Leon MB. Longterm outcomes of inoperable patients with aortic stenosis randomly assigned to transcatheter aortic valve replacement or standard therapy. Circulation. 2014;130:1483-92.

19. Leon MB, Smith CR, Mack M, Miller DC, Moses JW, Svensson LG, Tuzcu EM, Webb JG, Fontana GP, Makkar RR, Brown DL, Block PC, Guyton RA, Pichard AD, Bavaria JE, Herrmann HC, Douglas PS, Petersen JL, Akin JJ, Anderson WN, Wang D, Pocock S; PARTNER Trial Investigators. Transcatheter 
aortic-valve implantation for aortic stenosis in patients who cannot undergo surgery. N Engl J Med. 2010;363:1597-607.

20. Yousef A, MacDonald Z, Simard T, Russo JJ, Feder J, Froeschl MV, Dick A, Glover C, Burwash IG, Latib A, RodésCabau J, Labinaz M, Hibbert B. Transcatheter Aortic Valve Implantation (TAVI) for Native Aortic Valve Regurgitation A Systematic Review. Circ J. 2018;82:895-902.

21. Tung M, Wang X, Li F, Wang H, Guo Y, Wang C, Wei L, Luo X, Wang X, Wang W. A versatile transapical device for aortic valvular disease: One-year outcomes of a multicenter study on the J-Valve system. J Cardiol. 2018;72:377-84.

22. Matthew Brennan J, Leon MB, Sheridan P, Boero IJ, Chen Q, Lowenstern A, Thourani V, Vemulapalli S, Thomas K, Wang TY, Peterson ED. Racial Differences in the Use of Aortic Valve Replacement for Treatment of Symptomatic Severe Aortic Valve Stenosis in the Transcatheter Aortic Valve Replacement Era. J Am Heart Assoc. 2020;9:e015879.

23. Hon JKF, Tay E. Transcatheter aortic valve implantation in Asia. Ann Cardiothorac Surg. 2017;6:504-9.

24. Yoon SH, Ohno Y, Araki M, Barbanti M, Lin MS, Ahn JM, Yang DH, Kim YH, Immé S, Gulino S, Tamburino CI, Sgroi C, Park DW, Kang SJ, Lee SW, Lee CW, Park SW, Muramatsu T, Kao HL, Tamburino C, Park SJ. Comparison of aortic root anatomy and calcification distribution between Asian and Caucasian patients who underwent transcatheter aortic valve implantation. $\mathrm{Am} \mathrm{J}$ Cardiol. 2015;116:1566-73.

25. Ribeiro HB, Webb JG, Makkar RR, Cohen MG, Kapadia SR, Kodali S, Tamburino C, Barbanti M, Chakravarty T, Jilaihawi H, Paradis JM, de Brito FS Jr, Cánovas SJ, Cheema AN, de Jaegere PP, del Valle R, Chiam PTL, Moreno R, Pradas G, Ruel M, SalgadoFernández J, Sarmento-Leite R, Toeg HD, Velianou JL, Zajarias A, Babaliaros V, Cura F, Dager AE, Manoharan G, Lerakis S, Pichard AD, Radhakrishnan S, Perin MA, Dumont E, Larose E, Pasian SG, Nombela-Franco L, Urena M, Tuzcu EM, Leon MB, Amat-Santos IJ, Leipsic J, Rodés-Cabau J. Predictive factors, management, and clinical outcomes of coronary obstruction following transcatheter aortic valve implantation: insights from a large multicenter registry. J Am Coll Cardiol. 2013;62:1552-62.

26. Yoon SH, Ahn JM, Hayashida K, Watanabe Y, Shirai S, Kao HL, Yin WH, Lee MK, Tay E, Araki M, Yamanaka F, Arai T, Lin MS, Park JB, Park DW, Kang SJ, Lee SW, Kim YH, Lee Cheol W, Park SW, Muramatsu T, Hanyu M, Kozuma K, Kim HS, Saito S, Park SJ; Asian TAVR Investigators. Clinical Outcomes Following Transcatheter Aortic Valve Replacement in Asian Population. JACC Cardiovasc Interv. 2016;9:926-33.

27. Watanabe Y, Hayashida K, Takayama M, Mitsudo K, Nanto S, Takanashi S, Komiya T, Kuratani T, Tobaru T, Goto T, Lefèvre T, Sawa Y, Morice MC. First direct comparison of clinical outcomes between European and Asian cohorts in transcatheter aortic valve implantation: The Massy study group vs. the PREVAIL JAPAN trial. J Cardiol. 2015;65:112-6.

28. Winter MP, Bartko P, Hofer F, Zbiral M, Burger A, Ghanim B, Kastner J, Lang IM, Mascherbauer J, Hengstenberg C, Goliasch G. Evolution of outcome and complications in TAVR: a meta-analysis of observational and randomized studies. Sci Rep. 2020; $10: 15568$

\section{Supplementary data}

Supplementary Table 1. Reasons for exclusion of full articles.

Supplementary Table 2. Appraisal of the cohort studies.

Supplementary Table 3. Appraisal of the case series.

Supplementary Table 4. Appraisal of the case reports.

Supplementary Figure 1. Forest plots outlining the effect size of each study for device success.

Supplementary Figure 2. Forest plots outlining the effect size of each study for 30-day all-cause mortality.

The supplementary data are published online at:

https://www.asiaintervention.org/

doi/10.4244/AIJ-D-21-00007 


\section{Supplementary data}

Supplementary Table 1. Appraisal of the cohort studies.

\begin{tabular}{|c|c|c|c|c|c|c|c|c|c|}
\hline & \multicolumn{4}{|c|}{ Selection } & \multirow{2}{*}{$\begin{array}{l}\text { Comparability } \\
\text { Comparability of cohorts } \\
\text { on the basis of the design } \\
\text { or analysis }\end{array}$} & \multicolumn{3}{|c|}{ Exposure } & \multirow[b]{2}{*}{$\begin{array}{l}\text { Total } \\
\text { score }\end{array}$} \\
\hline $\begin{array}{l}\text { Author, } \\
\text { year }\end{array}$ & $\begin{array}{l}\text { Representativeness } \\
\text { of the exposed cohort }\end{array}$ & $\begin{array}{l}\text { Selection } \\
\text { of the non- } \\
\text { exposed } \\
\text { cohort }\end{array}$ & $\begin{array}{l}\text { Ascertainment } \\
\text { of exposure }\end{array}$ & $\begin{array}{l}\text { Demonstration } \\
\text { that outcome } \\
\text { of interest was } \\
\text { not present at } \\
\text { start of study }\end{array}$ & & $\begin{array}{l}\text { Ascertainment } \\
\text { of outcome }\end{array}$ & $\begin{array}{l}\text { Was follow-up } \\
\text { long enough for } \\
\text { outcomes to } \\
\text { occur }\end{array}$ & $\begin{array}{l}\text { Adequacy of } \\
\text { follow up of } \\
\text { cohorts }\end{array}$ & \\
\hline $\begin{array}{l}\text { Deng } \\
\text { M.D., } \\
2018\end{array}$ & $*$ & $*$ & $*$ & $*$ & $* *$ & $*$ & $*$ & $*$ & 9 stars \\
\hline
\end{tabular}


Supplementary Table 2. Appraisal of the case series.

\begin{tabular}{|c|c|c|c|c|c|c|c|c|c|c|}
\hline \multicolumn{11}{|c|}{ CASE SERIES } \\
\hline \multirow[b]{2}{*}{ Author, year } & \multirow{2}{*}{\begin{tabular}{|l|}
\multicolumn{1}{|c|}{$\begin{array}{c}\text { Study } \\
\text { objective }\end{array}$} \\
$\begin{array}{l}\text { Was the } \\
\text { hypothesis/aim/ } \\
\text { objective of the } \\
\text { study clearly } \\
\text { stated? }\end{array}$ \\
\end{tabular}} & \multicolumn{3}{|c|}{ Study design } & \multicolumn{3}{|c|}{ Study population } & \multicolumn{2}{|c|}{$\begin{array}{c}\text { Intervention and co- } \\
\text { intervention }\end{array}$} & $\begin{array}{c}\text { Competing } \\
\text { interests } \\
\text { and sources } \\
\text { of support }\end{array}$ \\
\hline & & $\begin{array}{l}\text { Was the study } \\
\text { conducted } \\
\text { prospectively? }\end{array}$ & 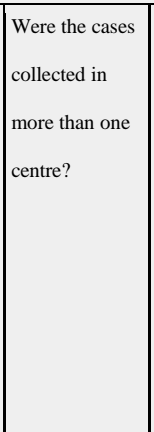 & $\begin{array}{l}\text { Were patients } \\
\text { recruited } \\
\text { consecutively? }\end{array}$ & $\begin{array}{l}\text { Were the } \\
\text { characteristics } \\
\text { of the patients } \\
\text { included in } \\
\text { the study } \\
\text { described? }\end{array}$ & \begin{tabular}{|l} 
Were the \\
eligibility \\
criteria (i.e., \\
inclusion and \\
exclusion \\
criteria) for \\
entry into the \\
study clearly \\
stated?
\end{tabular} & \begin{tabular}{|l} 
Did patients \\
enter the \\
study at a \\
similar point \\
in the \\
disease?
\end{tabular} & \begin{tabular}{|l} 
Was the \\
intervention \\
of interest \\
clearly \\
described?
\end{tabular} & \begin{tabular}{|l} 
Were \\
additional \\
interventions \\
(co- \\
interventions) \\
clearly \\
described?
\end{tabular} & \begin{tabular}{|l} 
Were both \\
competing \\
interests and \\
sources of \\
support for the \\
study reported?
\end{tabular} \\
\hline \multirow{4}{*}{$\begin{array}{l}\text { Liu L. L., } \\
2019\end{array}$} & Yes & No & No & Yes & Yes & Yes & Yes & Yes & Partial & Yes \\
\hline & \multicolumn{4}{|c|}{ Outcome measure } & $\begin{array}{r}\text { Statistical } \\
\text { analysis }\end{array}$ & \multicolumn{5}{|c|}{ Results and conclusions } \\
\hline & \begin{tabular}{|l|} 
Were relevant \\
outcome \\
measures \\
established a \\
priori?
\end{tabular} & \begin{tabular}{|l} 
Were outcome \\
assessors \\
blinded to the \\
intervention \\
that patients \\
received?
\end{tabular} & \begin{tabular}{|l|} 
Were the \\
relevant \\
outcomes \\
measured using \\
appropriate \\
objective/subje \\
ctive methods?
\end{tabular} & \begin{tabular}{|l|} 
Were the \\
relevant \\
outcome \\
measures made \\
before and after \\
the intervention?
\end{tabular} & $\begin{array}{l}\text { Were the } \\
\text { statistical tests } \\
\text { used to assess } \\
\text { the relevant } \\
\text { outcomes } \\
\text { appropriate? }\end{array}$ & \begin{tabular}{|l} 
Was follow-up \\
long enough for \\
important \\
events and \\
outcomes to \\
occur?
\end{tabular} & $\begin{array}{l}\text { Were losses } \\
\text { to follow-up } \\
\text { reported? }\end{array}$ & \begin{tabular}{|l} 
Did the study \\
provide \\
estimates of \\
random \\
variability in \\
the data \\
analysis of \\
relevant \\
outcomes?
\end{tabular} & \begin{tabular}{|l} 
Were the \\
adverse events \\
reported?
\end{tabular} & \begin{tabular}{|l} 
Were the \\
conclusions of \\
the study \\
supported by \\
results?
\end{tabular} \\
\hline & Yes & Unclear & Yes & Yes & Yes & Yes & Yes & No & Yes & Yes \\
\hline $\begin{array}{l}\text { Author, } \\
\text { year }\end{array}$ & $\begin{array}{c}\text { Study } \\
\text { objective }\end{array}$ & & Study design & & & udy populat & & $\begin{array}{r}\text { Interven } \\
\text { inter }\end{array}$ & $\begin{array}{l}\text { ion and co- } \\
\text { vention }\end{array}$ & $\begin{array}{c}\text { Competing } \\
\text { interests } \\
\text { and sources } \\
\text { of support }\end{array}$ \\
\hline
\end{tabular}




\begin{tabular}{|c|c|c|c|c|c|c|c|c|c|c|}
\hline & $\begin{array}{l}\text { Was the } \\
\text { hypothesis/aim/ } \\
\text { objective of the } \\
\text { study clearly } \\
\text { stated? }\end{array}$ & $\begin{array}{l}\text { Was the study } \\
\text { conducted } \\
\text { prospectively? }\end{array}$ & $\begin{array}{l}\text { Were the cases } \\
\text { collected in } \\
\text { more than one } \\
\text { centre? }\end{array}$ & $\begin{array}{l}\text { Were patients } \\
\text { recruited } \\
\text { consecutively? }\end{array}$ & $\begin{array}{l}\text { Were the } \\
\text { characteristics } \\
\text { of the patients } \\
\text { included in } \\
\text { the study } \\
\text { described? }\end{array}$ & $\begin{array}{l}\text { Were the } \\
\text { eligibility } \\
\text { criteria (i.e., } \\
\text { inclusion and } \\
\text { exclusion } \\
\text { criteria) for } \\
\text { entry into the } \\
\text { study clearly } \\
\text { stated? }\end{array}$ & $\begin{array}{l}\text { Did patients } \\
\text { enter the } \\
\text { study at a } \\
\text { similar point } \\
\text { in the } \\
\text { disease? }\end{array}$ & $\begin{array}{l}\text { Was the } \\
\text { intervention } \\
\text { of interest } \\
\text { clearly } \\
\text { described? }\end{array}$ & $\begin{array}{l}\text { Were } \\
\text { additional } \\
\text { interventions } \\
\text { (co- } \\
\text { interventions) } \\
\text { clearly } \\
\text { described? }\end{array}$ & $\begin{array}{l}\text { Were both } \\
\text { competing } \\
\text { interests and } \\
\text { sources of } \\
\text { support for the } \\
\text { study reported? }\end{array}$ \\
\hline & Yes & Yes & Yes & Unclear & Yes & Yes & Yes & Yes & No & Yes \\
\hline & \multicolumn{4}{|c|}{ Outcome measure } & $\begin{array}{c}\text { Statistical } \\
\text { analysis }\end{array}$ & \multicolumn{5}{|c|}{ Results and conclusions } \\
\hline Liu H., & $\begin{array}{l}\text { Were relevant } \\
\text { outcome } \\
\text { measures } \\
\text { established a } \\
\text { priori? }\end{array}$ & $\begin{array}{l}\text { Were outcome } \\
\text { assessors } \\
\text { blinded to the } \\
\text { intervention } \\
\text { that patients } \\
\text { received? }\end{array}$ & $\begin{array}{l}\text { Were the } \\
\text { relevant } \\
\text { outcomes } \\
\text { measured using } \\
\text { appropriate } \\
\text { objective/subje } \\
\text { ctive methods? }\end{array}$ & $\begin{array}{l}\text { Were the } \\
\text { relevant } \\
\text { outcome } \\
\text { measures made } \\
\text { before and after } \\
\text { the intervention? }\end{array}$ & $\begin{array}{l}\text { Were the } \\
\text { statistical tests } \\
\text { used to assess } \\
\text { the relevant } \\
\text { outcomes } \\
\text { appropriate? }\end{array}$ & $\begin{array}{l}\text { Was follow-up } \\
\text { long enough for } \\
\text { important } \\
\text { events and } \\
\text { outcomes to } \\
\text { occur? }\end{array}$ & $\begin{array}{l}\text { Were losses } \\
\text { to follow-up } \\
\text { reported? }\end{array}$ & $\begin{array}{l}\text { Did the study } \\
\text { provide } \\
\text { estimates of } \\
\text { random } \\
\text { variability in } \\
\text { the data } \\
\text { analysis of } \\
\text { relevant } \\
\text { outcomes? }\end{array}$ & $\begin{array}{l}\text { Were the } \\
\text { adverse events } \\
\text { reported? }\end{array}$ & $\begin{array}{l}\text { Were the } \\
\text { conclusions of } \\
\text { the study } \\
\text { supported by } \\
\text { results? }\end{array}$ \\
\hline 2018 & Yes & Unclear & Yes & Yes & Unclear & Yes & Yes & No. & Yes & Yes \\
\hline
\end{tabular}


Supplementary Table 3. Appraisal of the case reports.

\begin{tabular}{|c|c|c|c|c|c|c|c|c|c|}
\hline & Selection & Ascert & ainment & & Caus & sality & & Reporting & \\
\hline Author, year & $\begin{array}{l}\text { 1. Does the } \\
\text { patient(s) } \\
\text { represent(s) the } \\
\text { whole experience } \\
\text { of the investigator } \\
\text { (centre) or is the } \\
\text { selection method } \\
\text { unclear to the } \\
\text { extent that other } \\
\text { patients with } \\
\text { similar } \\
\text { presentation may } \\
\text { not have been } \\
\text { reported? }\end{array}$ & $\begin{array}{l} \\
\text { 2. Was the } \\
\text { exposure } \\
\text { adequately } \\
\text { ascertained? }\end{array}$ & $\begin{array}{l}\text { 3. Was the } \\
\text { outcome } \\
\text { adequately } \\
\text { ascertained? }\end{array}$ & $\begin{array}{l} \\
\text { 4. Were other } \\
\text { alternative causes } \\
\text { that may explain } \\
\text { the observation } \\
\text { ruled out? }\end{array}$ & $\begin{array}{l}\text { 5. Was there a } \\
\text { challenge/rechalle } \\
\text { nge phenomenon? }\end{array}$ & $\begin{array}{l}\text { 6. Was there a } \\
\text { dose-response } \\
\text { effect? }\end{array}$ & $\begin{array}{l}\text { 7. Was follow-up } \\
\text { long enough for } \\
\text { outcomes to } \\
\text { occur? }\end{array}$ & $\begin{array}{l}\text { 8. Is the case(s) } \\
\text { described with } \\
\text { sufficient details } \\
\text { to allow other } \\
\text { investigators to } \\
\text { replicate the } \\
\text { research or to } \\
\text { allow } \\
\text { practitioners to } \\
\text { make inferences } \\
\text { related to their } \\
\text { own practice? }\end{array}$ & $\begin{array}{l}\text { Total } \\
\text { score }\end{array}$ \\
\hline $\begin{array}{l}\text { Chiam P. T., } \\
2014\end{array}$ & Yes & Yes & Yes & NA & NA & NA & Yes & Yes & 5 \\
\hline $\begin{array}{l}\text { Kurazumi, } \\
\text { H., } 2014\end{array}$ & $\begin{array}{l}\text { No } \\
\text { information } \\
\text { provided }\end{array}$ & $\begin{array}{l}\text { No } \\
\text { information } \\
\text { provided }\end{array}$ & Yes & 10 & NA & NA & Yes & Yes & 3 \\
\hline Zhu D., 2015 & 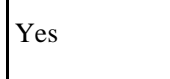 & Yes & Yes & NA & NA & NA & Yes & Yes & 5 \\
\hline Liu, W., 2019 & $\begin{array}{l}\text { No } \\
\text { information } \\
\text { provided }\end{array}$ & Yes & No & NA & NA & NA & No & Yes & 2 \\
\hline $\begin{array}{l}\text { Gopalamuru } \\
\text { gan A. B., } \\
2016\end{array}$ & Yes & Yes & Yes & NA & NA & NA & Yes & Yes & 5 \\
\hline Liu, X., 2016 & $\begin{array}{l}\text { No } \\
\text { information } \\
\text { provided }\end{array}$ & $\begin{array}{l}\text { No } \\
\text { information } \\
\text { provided }\end{array}$ & Yes & NA & NA & NA & $\begin{array}{l}\text { No } \\
\text { information } \\
\text { provided }\end{array}$ & Yes & 2 \\
\hline $\begin{array}{l}\text { Tan B. Y. Q., } \\
2017\end{array}$ & $\begin{array}{l}\text { No } \\
\text { information }\end{array}$ & Yes & Yes & NA & NA & NA & Yes & No & 3 \\
\hline
\end{tabular}




\begin{tabular}{|l|l|l|l|l|l|l|l|l|l|}
\hline & provided & & & & & & & & \\
\hline $\begin{array}{l}\text { Cheung G. S. } \\
\text { H., } 2017\end{array}$ & Yes & Yes & Yes & NA & NA & NA & Yes & Yes & 5 \\
\hline
\end{tabular}

Note: Abstracts were not appraised as there is no validated tool to do so.

Supplementary Table 4. Reasons for exclusion of full articles.

\begin{tabular}{|l|r|}
\hline Reasons for exclusion of full articles & Total: 51 \\
\hline Article could not be found & 2 \\
\hline Wrong population & 24 \\
\hline Wrong procedure & 8 \\
\hline No information on outcomes & 15 \\
\hline Repeated patient pool & \\
\hline
\end{tabular}




\section{Forest Plot}

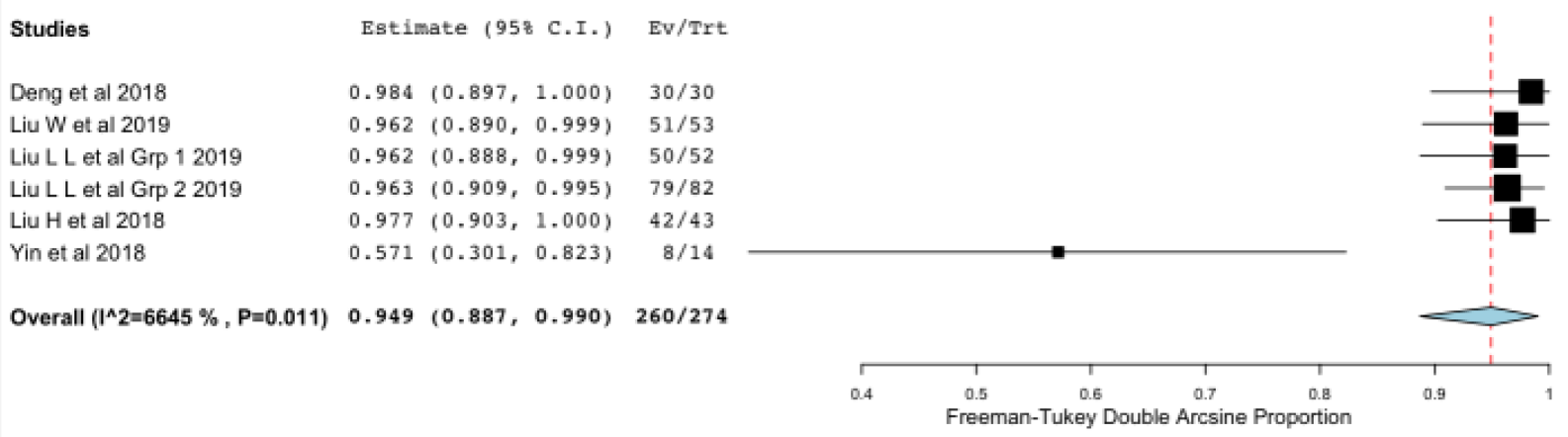

Supplementary Figure 1. Forest plots outlining the effect size of each study for device success.

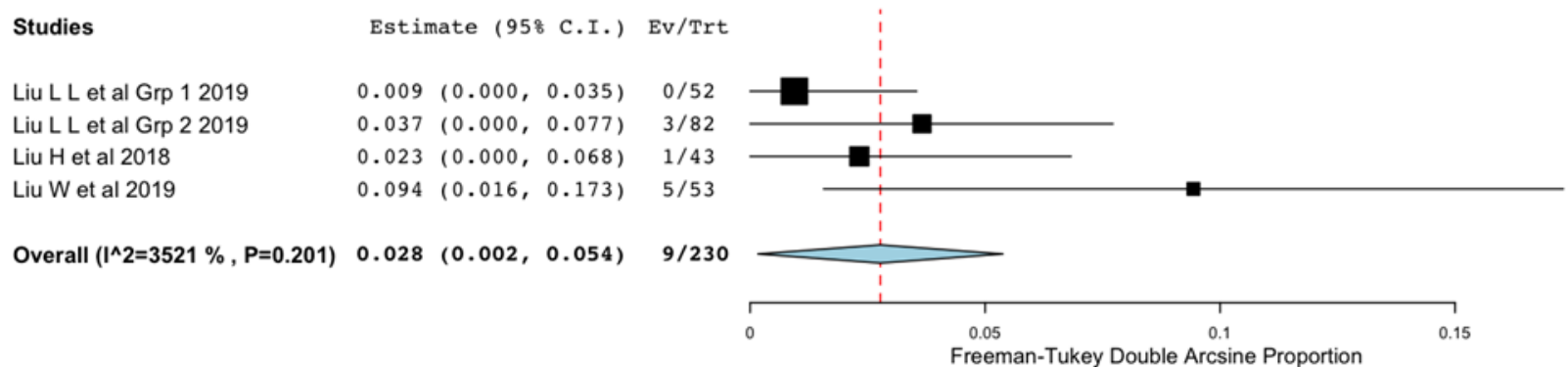

Supplementary Figure 2. Forest plots outlining the effect size of each study for 30-day all-cause mortality. 